\title{
Formy siedzib średnich i niższych rangą urzędników krzyżackich w granicach obecnej Polski
}

\section{Forms of medium and lower rank Teutonic Order officials' seats within the borders of present Poland}

Zarys treści. Spośród około 70 siedzib średnich i niższych rangą urzędników krzyżackich (wójtów, prokuratorów, leśnych, rybickich oraz nienależących do korporacji zakonnej komorników) w granicach obecnej Polski blisko połowa była przedmiotem badań archeologicznych, jednak stan rozpoznania znacznej ich części jest niewystarczający. Należy jednak stwierdzić, że mimo tego zastrzeżenia można sformułować pewne wnioski. Wspomniane siedziby były bardzo zróżnicowane pod względem form i funkcji. Wśród nich możemy wyróżnić monumentalne obiekty o charakterze pałacowym (np. nieregularny zamek w Sztumie), niewielkie, murowane wieże mieszkalno-obronne (np. zamek w Ełku), budowle o lżejszych konstrukcjach (siedziba prokuratora w Pniu), a także zamki nawiązujące formą do kaszteli konwentualnych (zamek w Szczytnie). Obecny stan badań zmusza do rewizji rozpowszechnionego w literaturze poglądu, że zamki wójtowskie były większe od prokuratorskich, najmniejsze zaś były siedziby leśnych, rybickich i komorników. Zdarzało się, że siedziby wójtów były mniejsze niż prokuratorów. Niektóre zamki prokuratorskie dorównywały skalą dużym założeniom wójtowskim, a siedziby leśnych, rybickich i komorników nie odbiegały od wielu siedzib prokuratorów. $Z$ tego względu nie należy stosować określeń: „,model zamku wójtowskiego”, „,model zamku prokuratorskiego” albo „model zamku komornickiego”.

Słowa kluczowe: zamki krzyżackie, stan badań, dwory krzyżackie, Prusy krzyżackie, architektura obronna, średniowiecze, archeologia.

Niemal połowa siedzib urzędników poniżej rangi komtura, które znajdują się w granicach obecnej Polski, stanowiła przedmiot badań archeologicznych. W niniejszym zestawieniu uwzględniono jedynie te zajmowane przez urzędników 
zarządzających okręgami administracyjnymi, a także komorników niebędących członkami Zakonu. W sumie można wskazać około 70 obiektów stanowiących w średniowieczu siedziby wójtów, prokuratorów, leśnych, rybickich i komorników (Voigt 1843; Jähnig 2000; Jóźwiak 2012).

Na wstępie należy odpowiedzieć na pytanie, ile z badanych archeologicznie siedzib zostało rozpoznanych w stopniu wstępnym, ile w bardziej zaawansowanym. Niektóre prace wykopaliskowe pozwoliły jedynie na zorientowanie się w układzie nawarstwień kulturowych części stanowiska. Możemy tu wskazać Benowo (Chęć 2004; Chęć, Janowski 2005), Bratian (Grążawski 2010; 2015; Grążawski, Grążawska 2013), Mątowy Małe (Chęć 2003a; 2003b), Grabiny-Zameczek (Kochanowski 1998/1999), Starą Kiszewę (Hołowińska 1975), Węgorzewo (Łapo 1996; 1999), Pasłęk i Przezmark ${ }^{1}$. Nieco lepiej rozpoznano zabudowę siedzib w Piszu (Gula 2003a), Osieku (Muntowski 2013) i Giżycku (Gula, Ślaske 1969; Piotrowski 2010; 2011), jednak trudno uznać stopień ich rozpoznania za satysfakcjonujący. Pozostałe obiekty, będące przedmiotem badań archeologicznych, są rozpoznane w stopniu o wiele bardziej zaawansowanym, choć nadal na wiele pytań nie udało się odpowiedzieć. Część z nich doczekała się monografii, na przykład Pień (Poliński 2013), Bezławki (Bezławki 2013) i Puck (Kruppé, Milewska 2014).

Celem artykułu jest przedstawienie wybranych zagadnień dotyczących form tych obiektów. Literatura odnosząca się do zamków komturskich jest bardzo bogata, natomiast siedziby średnich i niższych rangą urzędników krzyżackich nie doczekały się dotychczas nawet wstępnego, ogólnego opracowania, nie licząc pracy magisterskiej (Grzywacz 2003), a o podjęcie szerszych studiów nad tym zagadnieniem apelowano już w literaturze kilkanaście lat temu (Andrzejewski, Kajzer 2005, s. 203). Kilku autorów analizowało je na szerszym tle (Frycz 1978; Kajzer 2007; Knyżewski 2015), jednak wciąż nie ma pracy podsumowującej, w której próbowano by dokonać analizy występowania konkretnych form architektonicznych w czasie i przestrzeni. Poniżej także nie zaprezentuję wyczerpującego studium dotyczącego tych zagadnień, ale ustosunkuję się jedynie do hipotez, które ugruntowały się już w literaturze. Artykuł ten ma również stanowić swego rodzaju podsumowanie i streszczenie stanu badań terenowych nad tytułowymi obiektami. Należy jednak zastrzec, że zostaną tutaj przytoczone prace trenowe, których wyniki miały istotne znaczenie dla przedmiotu badań. Według rozpowszechnionej opinii dotyczącej zamków niższych urzędników krzyżackich siedziby wójtowskie były większe od prokuratorskich, najmniejsze były zamki i dwory, w których rezydowali rybiccy, leśni i komornicy (Jackiewicz-Garniec, Garniec, 2009, s. 48-57; Torbus, 2010, s. 13). Zwróćmy jednak uwagę, że niektóre założenia powstały jako prokuratorskie i dopiero po pewnym czasie zmieniała się nazwa urzędu w danym ośrodku (np. w Pasłęku, Przezmarku i Działdowie z prokuratorskich na wójtowskie). Istniały także stosunkowo znacznych rozmiarów zamki, dla których nie ma

${ }^{1}$ O badaniach w Pasłęku i Przezmarku - por. w tym tomie. 
poświadczonych wójtów, a jedynie prokuratorzy. Przykładem może być obiekt w Węgorzewie, który wymaga jednak dalszych badań terenowych. Dotychczas miały miejsce jedynie próby analizy archiwalnej dokumentacji z inwentaryzacji architektonicznych (Wołosz 1998) oraz wspomniane wyżej, prowadzone w bardzo skromnym zakresie, prace archeologiczne. Z kolei zamek w Działdowie został zapewne rozbudowany wraz ze zmianą tytulatury tamtejszego urzędnika z prokuratora na wójta, ale mogło to wynikać z innych przyczyn (np. zmiany sytuacji na granicy z Mazowszem, większego nacisku na funkcje gospodarcze), które zbiegły się w czasie z pojawieniem się wójtów działdowskich (Knyżewski 2015, s. 262-263).

Spośród dużych siedzib wójtowskich z pewnością należy wyróżnić zamek w Sztumie, który w pierwszej fazie wzniesiono w latach 20. i 30. XIV wieku. To monumentalne założenie architektoniczne było rozbudowywane niemal przez cały czas funkcjonowania w państwie zakonnym (Torbus 1997). Jego wyjątkowy charakter wynikał także z faktu, że z czasem stał się jedną z ulubionych siedzib wielkich mistrzów.

Zamek Bratian powstał przed połową XIV wieku². Główna część założenia powstała na rzucie zbliżonym do kwadratu z cylindryczną wieżą w narożu. W północnej partii znajdował się dom główny. Przy wschodniej kurtynie istniał - być może już w średniowieczu, ponieważ został opisany już w XVI wieku - budynek o murowanym przyziemiu i wyższych kondygnacjach w lżejszej, szkieletowej konstrukcji. Po zachodniej stronie wzniesiono natomiast inne budynki gospodarcze. Przedzamcze było nieregularne.

Zupełnie inne założenie stanowiło siedzibę wójta w Dąbrównie. Zdaniem Sławomira Jóźwiaka tamtejszy urzędnik był najważniejszym przedstawicielem krzyżackiej administracji na obszarze ziemi sasińskiej do czasu utworzenia komturstwa w Ostródzie na przełomie 1340 i 1341 roku (Jóźwiak 2000, s. 10). W starszej literaturze przyjmowano, że w Dąbrównie istniały dwa zamki (Czubiel 1986, s. 11-14). W latach 80. XX wieku prowadzono badania w miejscu, które było utożsamiane z lokalizacją murowanego zamku. Wykluczyły one możliwość istnienia w tym miejscu krzyżackiej warowni (Poklewski 1992). Natomiast blisko trzy dekady wcześniej archeolodzy prowadzili badania na kopcu znajdującym się około $100 \mathrm{~m}$ od dawnych murów miejskich. Obiekt, który znajdował się na nim w czasach krzyżackich stanowił zapewne założenie drewniano-ziemne, chociaż odkryto bruk kamienny i pojedyncze fragmenty cegieł gotyckich (Dąbrowski 1961/1962). W świetle obecnego stanu badań wójt w Dąbrównie rezydował w mniej okazałym - od wcześniej wymienionych obiektów - dworze, który powstał na początku XIV wieku i znajdował się poza murami miejskimi.

Komentarza wymaga także założenie zamkowe w Morąu, wybudowane około lat 20. XIV wieku. Jego mury obwodowe miały kształt zbliżony do trapezu. $\mathrm{W}$ trakcie badań archeologicznych zadokumentowano relikty trzech gotyckich

${ }^{2}$ Najnowsze opracowanie - por. Wasik 2016, s. 304-306. 
budowli: wieży, budynku bramnego i wolno stojącego domu w południowo-wschodniej części dziedzińca (Gula 2003b, s. 34-36). Do tego czasu istniały różne koncepcje dotyczące rozplanowania zamku, ale później także powtarzane były błędne informacje; na przykład Tomasz Torbus napisał, że pierwotnie zamek najprawdopodobniej był trójskrzydłowym założeniem (Torbus 2010, s. 139). W popularnonaukowej pracy dotyczącej zamków krzyżackich pierwszą, gotycką fazę morąskiego zamku uznano za siedzibę prokuratora, a rozbudowaną, nowożytną i trójskrzydłową za fazę po ustanowieniu tutaj urzędu wójtowskiego (Jackiewicz-Garniec, Garniec 2009, s. 264-265); to stwierdzenie także powtórzyłem w jednym z opracowań (Knyżewski, 2015, s. 263). Jednak z badań archeologicznych wynika, że zamek powstał jako obiekt $\mathrm{z}$ jednym domem murowanym i jako taki funkcjonował również w czasie rezydowania w nim wójta. Został rozbudowany dopiero w okresie nowożytnym, nie zaś wraz ze zmianą tytulatury tamtejszego urzędnika.

Siedziby prokuratorskie także były bardzo zróżnicowane pod względem formy, można zaryzykować stwierdzenie, że najbardziej wśród siedzib średnich i niższych rangą urzędników krzyżackich. Powyżej wspomniałem o zamkach, które powstały jako prokuratorskie, z czasem tytulatura rezydujących w nich urzędników uległa zmianie, co nie oznaczało jednoczesnej zmiany form tych obiektów, które już od początku istnienia miały znaczne rozmiary. Powstawały także liczne mniejsze budowle murowane, stanowiące siedziby prokuratorów - w Giżycku i Ełku.

W Ełku znajdowała się wieża mieszkalno-obronna wybudowana na przełomie XIV i XV wieku. Teren wyspy zamkowej był przedmiotem badań archeologicznych, które w znacznym stopniu uszczegółowiły wiedzę o obiekcie. Zamek główny oddzielony był od przedzamcza fosą na planie zbliżonym do okręgu, przez którą po stronie wschodniej przerzucono most. Zarejestrowano także słabo czytelne ślady zabudowy przedzamcza w postaci smug próchniczych na calcu. W średniowieczu zamek nie miał murów obwodowych, jedynie przedzamcze było otoczone palisadą. Od strony wschodniej pierwotnie znajdowała się jeszcze jedna, niewielka wyspa. Być może na niej umieszczono wieżę, która widoczna jest na przedstawieniu z 1541 roku (ryc. 1). Mogła być to konstrukcja przynajmniej częściowo murowana, na co wskazują eksplorowane w tym rejonie warstwy gruzowe (Herman 2012, s. 13). Prawdopodobnie we wschodniej części głównej wyspy znajdował się ceglany budynek wzniesiony w XV lub na początku XVI wieku, który również został uwieczniony na najstarszym przedstawieniu zamku (Herman 2015).

Pochodzący z końca XIV i początku XV wieku dom zamkowy w Giżycku, podobnie jak opisany w Ełku, a także w Morągu, był wolno stojący, miał jednak bardziej horyzontalny układ od ełckiego. W trakcie badań archeologicznych odsłonięto tu relikty gdaniska, co jest wyjątkowe w przypadku niewielkich warowni krzyżackich (Piotrowski 2011). Co prawda na podobne pozostałości natrafiono w Barcianach, ale w tym przypadku obiekt znacznie różnił się skalą oraz pierwotnym przeznaczeniem (prawdopodobnie powstawał jako siedziba konwentu) 


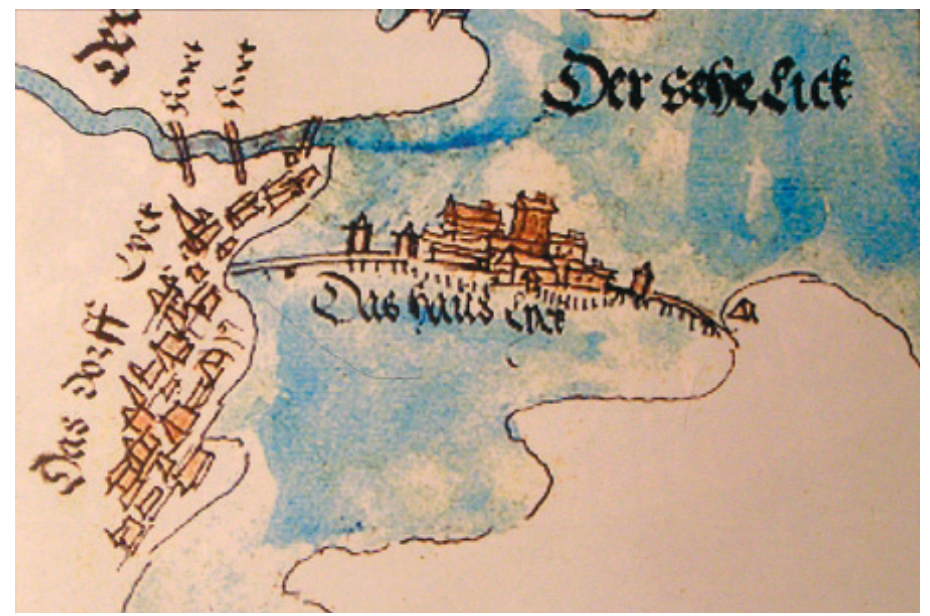

Ryc. 1. Ełk. Widok miasta i zamku na mapie z 1541 roku (wg Herman 2015)

Fig. 1. Ełk. View of the town and the castle on a map from 1541 (after Herman 2015)

od giżyckiego. Podobny dom znajdował się na terenie zamku w Nowym Jasińcu, ale początku jego budowy można się dopatrywać prawdopodobnie jeszcze w czasach przedkrzyżackich (Nawrocki 1967, s. 99).

Warto jeszcze wspomnieć o kilku innych siedzibach prokuratorskich; jedną z nich jest zamek w Piszu. Podczas badań archeologicznych zadokumentowano tam relikty pierwszej warowni, które pochodzą zapewne z lat 40. XIV wieku. Nie wykluczono jednak, że już wówczas na terenie zamku wybudowano pewne elementy murowane, zdaniem autora badań dom zamkowy mógł istnieć jako murowany w drewnianym obwodzie warownym (Gula 2003a). Po zniszczeniach spowodowanych najazdami litewskimi w latach 60. XIV wieku wzniesiono w tym miejscu nowy obiekt. Na podstawie wyników badań terenowych oraz nowożytnych planów założenia ustalono, że teren objęty murami liczył około $43 \times 100 \mathrm{~m}$. Odpowiadał on zapewne dwóm średniowiecznym członom zamku (przedzamczu i części głównej), ale w trakcie badań nie uchwycono reliktów oddzielających je murów. W średniowieczu znajdowało się tam jedno bądź dwa skrzydła murowane (Gula 2003a). Byłby to zatem bardziej rozbudowany zamek stanowiący siedzibę prokuratora od wymienionych powyżej obiektów w Ełku i Giżycku, ale jednocześnie nie tak rozległy jak założenia w Przezmarku i Pasłęku.

Dużo mniejszy był wzniesiony w zbliżonym czasie, tzn. zapewne około lat 70. i 80. XIV wieku zamek w Szestnie, który składał się z murów obwodowych na rzucie zbliżonym do kwadratu o boku około 25 m orazjednego murowanego domu. W miejscu tego założenia wcześniej - około połowy XIV wieku - również istniała drewniano-ziemna warownia krzyżacka (Głosek 1986). W przypadku zamków w Piszu i Szestnie mamy potwierdzone istnienie wcześniejszych drewnianych umocnień. 
Obiekty te powstały w podobnym czasie, miały teoretycznie podobną rangę, ale zupełnie inną skalę.

Ostatnia ćwierć XIV wieku przyniosła także pojedyncze bardziej monumentalne inwestycje wśród siedzib prokuratorskich. Należał do nich wspomniany już zamek w Węgorzewie, a także w Nidzicy, którego początek budowy był nieco wcześniejszy i przypadał zapewne na podobny czas jak budowa zamków w Szestnie i Piszu (lata 70. i 80. XIV wieku). Ten ostatni do dnia dzisiejszego prezentuje się jako wybitne dzieło architektury krzyżackiej. To założenie obronne powstało na rzucie wydłużonego prostokąta o wymiarach około $43 \times 61 \mathrm{~m}$. Składało się z zachodniego domu głównego, dwóch niższych bocznych skrzydeł oraz wschodniego masywu z dwiema prostokątnymi wieżami, flankującymi ryzalit bramy wjazdowej. Od wschodu znajdowało się również przedzamcze. Ponownie możemy zauważyć znaczną różnicę jakościową w architekturze obiektów, stanowiących siedziby urzędników o tej samej tytulaturze. Do tej grupy należy również zaliczyć zamek w Szczytnie, w miejscu którego odkryto wcześniejsze, datowane na około połowę XIV wieku, umocnienia drewniano-ziemne (Buczek-Płachtowa 1969; 1970). W ostatniej ćwierci XIV wieku powstało murowane założenie na rzucie zbliżonym do kwadratu o boku około $39 \mathrm{~m}$. Wyjątkowość polegała na wzniesieniu w jego obrębie czterech skrzydeł, co nawiązywało do rozpoznawalnych zamków konwentualnych. W jednym z naroży znajdowała się wieża, także świadcząca o wzorowaniu się na kasztelach środkowoeuropejskich (Durdik 1994). Nie mamy jednak wystarczających danych odnośnie do programu użytkowego tego obiektu. Być może źródła pisane skrywają jeszcze informacje w tej kwestii, ale jest to problem do wyjaśnienia przez historyków. Bez wiedzy na temat znajdujących się w obrębie zamku pomieszczeń, trudno mówić o typowym kasztelu konwentualnym. Mając na względzie powyższe uwagi trudno potwierdzić bezpośrednie wzorowanie się na zamkach konwentualnych przy wznoszeniu siedzib średnich i niższych urzędników krzyżackich.

Do większych warowni prokuratorskich, które powstały w końcu XIV wieku należy zamek w Bytowie na Pomorzu Gdańskim, do dzisiaj zachowany w bardzo dobrym stanie; był on przedmiotem badań archeologiczno-architektonicznych (Pawłowski 1993; 1994; Szczepanik 2013a; 2013b). Warownię wzniesiono na planie prostokąta o wymiarach około $49 \times 70 \mathrm{~m}$. W XV wieku w jej obrębie znajdował się jeden murowany dom. Zabudowę wewnątrz obwodu uzupełniała piętrowa kuchnia. W narożach murów wzniesiono trzy baszty oraz czworoboczną wieżę bezpośrednio przy domu zamkowym. Na dziedzińcu istniała także zapewne lżejsza, być może szkieletowa zabudowa. Był to obiekt wyjątkowy, bardzo nowoczesny - dostosowany do obrony z użyciem broni palnej, z dużym dziedzińcem. $Z$ całą pewnością można rozpatrywać go w znacznie szerszym kontekście przemian architektury militarnej, nie tylko jako jeden z zamków krzyżackich. 
Z Pomorza Gdańskiego pochodzą także inne duże założenia zamkowe zbudowane w końcu XIV i na początku XV wieku, należy do nich obiekt w Starej Kiszewie, jednak jego stan badań jest znikomy. Nieznana jest także ranga tamtejszego urzędnika (Grzegorz 1997, s. 138). W zbliżonym czasie powstała siedziba wójta w Grabinach-Zameczku. W tym przypadku dotychczas przeprowadzone badania można uznać za bardziej zaawansowane niż w Starej Kiszewie, ale również one nie pozwalają na bardziej szczegółowe rekonstrukcje tego obiektu (Kochanowski 1998/1999). Z pewną ostrożnością można jednak przyjąć, że w końcu XIV i początku XV wieku na wspomnianym terenie powstawały zamki, które nie wpisywały się w schematy architektury krzyżackiej i należy je rozpatrywać w szerszym kontekście architektury południowego pobrzeża Morza Bałtyckiego.

Pozostaje jeszcze kwestia siedziby prokuratorskiej w Pniu, która została wzniesiona na początku XV wieku i krótko funkcjonowała. Ograniczę się jednak tylko do pewnych ogólnych stwierdzeń na jej temat, ponieważ doczekała się ona już pokaźnej literatury (Poliński 2013 - tam starsza literatura). Dom stanowiący siedzibę urzędnika wybudowano zapewne w konstrukcji szachulcowej; miał on znaczne wymiary jak na tego rodzaju budynek - około $10 \times 13 \mathrm{~m}$. Obiekt ten jest na swój sposób wyjątkowy przy obecnym stanie badań i stanowi doskonały przykład, że w państwie zakonnym budowle drewniane wznoszono aż do XV wieku, a zapewne i dłużej.

Niewiele wśród siedzib leśnych, rybickich i komorników było dotychczas przedmiotem badań archeologicznych, jeszcze mniej z nich zachowało się do dzisiaj. W świetle tych skromnych danych można jednak stwierdzić, że ich układ przestrzenny nie odbiegał od wielu siedzib prokuratorskich.

Zamek rybickiego w Pucku, który powstał w ostatnich latach XIV lub na początku XV wieku, stanowił założenie z jednym niewielkim domem murowanym. Warownia w Bezławkach, która w literaturze uznawana jest najczęściej za komornicką (chociaż nie znajduje to potwierdzenia w źródłach pisanych), miała również jeden dom murowany, ale znalazł się on w całkiem pokaźnym obwodzie warownym na rzucie zbliżonym do prostokąta (około $42 \times 52 \mathrm{~m}$ ). W obrębie jego murów mogły zmieścić się niemal dwa zamki pokroju prokuratorskiej warowni w Szestnie. Nie będę w tym miejscu opisywał szczegółowo tych założeń, ponieważ niedawno doczekały się one publikacji (por. wyżej).

Zamek w Sątocznie, stanowiący siedzibę leśnego, składał się natomiast z dwóch członów: jednym była murowana wieża na kopcu otoczonym fosą, drugim majdan zamknięty umocnieniami drewniano-ziemnymi (Andrzejewski, Kajzer 2001; 2002-2003; 2005). Obiekt ten powstał kilkadziesiąt lat wcześniej niż wieża mieszkalno-obronna w Ełku, można go datować na około połowę XIV wieku, w pewnym stopniu może ją jednak przypominać. Nawiązywał do wczesnych warowni w typie donżonów, które były bardzo powszechne na terenie Europy Zachodniej. Różnice w rozplanowaniu zabudowy w Ełku i Sątocznie wynikały 
w głównej mierze z warunków terenowych. Wieża w Ełku została wzniesiona na wyspie i dodatkowo otoczona fosą, która oddzielała ją od pozostałych zabudowań, znajdujących się na mniejszych wyspach, a poszczególne człony założenia były skomunikowane za pomocą mostów. Dom zamkowy w Sątocznie powstał na wzniesieniu odgrodzonym fosą, zaś przedzamcze stanowiło jedną całość zamkniętą obwodem warownym.

Badania archeologiczne w Olsztynku w znacznej mierze zmieniły wyobrażenie o tamtejszym średniowiecznym zamku, w którym rezydował komornik (Koperkiewicz, Świętosławski 2006; Koperkiewicz 2007). Jego budowa rozpoczęła się być może już w końcu lat 40. XIV wieku, ale większość prac miała miejsce prawdopodobnie w pierwszych kilkunastu latach 2. połowy XIV wieku. Do niedawna znaczna część badaczy przyjmowała, że zamek komornicki był niewielkim obiektem na rzucie zbliżonym do kwadratu z jednym domem o długości około 28 m (Torbus 2010, s. 167). Badania archeologiczne wykazały istnienie już w XIV wieku przeciwnie usytuowanego drugiego skrzydła . Okazało się, że jest to prawdopodobnie jedyny znany, potwierdzony przykład budowli krzyżackiej z dwoma równolegle usytuowanymi domami, które zdaniem Tomasz Torbusa miały się rozpowszechniać w budownictwie państwa zakonnego od lat 40. XIV wieku (Torbus 2014, s. 268). Oprócz zamku w Olsztynku należy wskazać także siedziby biskupie i kapitulne, czyli budowle w Olsztynie i Reszlu. Nie można wykluczać, że istniały także inne zamki mające dwa skrzydła, ale wymaga to badań archeologiczno-architektonicznych. W świetle obecnego stanu wiedzy wydaje się jednak, że model zamku dwudomowego, który był bardzo popularny na przykład w luksemburskich Czechach (Durdík 1998), ale także nieco później w Wielkopolsce (Pietrzak 2005), rzadko występował na terenie państwa zakonnego.

Wśród innych siedzib rybickich, leśnych i komorników, które stanowiły przedmiot badań archeologicznych należy jeszcze wspomnieć dwór w Benowie, ale tak jak w wielu innych przypadkach, ze względu na zbyt skromną skalę dotychczasowych prac terenowych, nie możemy podjąć próby rekonstrukcji tego założenia.

Nie wymieniłem wszystkich siedzib urzędników krzyżackich, które były przedmiotem badań archeologicznych, warto jeszcze wspomnieć o jednej, należącej do nieznanego bliżej urzędnika, znajdującej się w Skarszewach. Badania terenowe, którymi kierowała Martyna Milewska (1993), umożliwiły podjęcie próby rekonstrukcji tego obiektu. Powstały po 1370 roku zamek stanowił założenie nieregularne. Główny dom wzniesiono na rzucie prostokąta o wymiarach około $14 \times 36$ m; przylegała do niego wieża od północnej strony elewacji. Po 1433 roku dobudowano kolejną wieżę przy wschodniej elewacji południowego narożnika. Także w Osieku prowadzono badania - o stosunkowo niewielkim zakresie - które pozwoliły uszczegółowić dotychczasowe rekonstrukcje zamku prokuratorskiego, ale nie wpłynęły znacząco na sposób postrzegania tego obiektu powstałego na 
rzucie zbliżonym do podkowy w 2. połowie XIV wieku. Oba założenia wzniesiono stosunkowo późno jak na nieregularne zamki krzyżackie, które pojawiły się po połowie XIII wieku. Wśród nieregularnych, późnych siedzib średnich i niższych urzędników krzyżackich wspomnieć trzeba o wzmiankowanym wcześniej zamku w Węgorzewie.

Na zamku w Nowem, stanowiącym siedzibę bliżej nieokreślonego urzędnika zarządzającego okręgiem administracyjnym na terenie wójtostwa tczewskiego, miały miejsce badania archeologiczne (Partyka-Żukowska 1977), ale dokumentacja z nich nie zachowała się w całości; nie zmieniły one też jego ogólnego obrazu. Warownia była zintegrowana $\mathrm{z}$ fortyfikacjami miejskimi i powstała w 2. połowie XIV wieku. Główny dom wzniesiono na rzucie prostokąta o wymiarach około $12 \times 39$ m. Być może już w średniowieczu (trudno jednak dokładnie określić kiedy), przylegało do niego od północy drugie skrzydło. Nie wiemy jaką rangę posiadał tamtejszy urzędnik, ale skala i rozplanowanie założenia nie odbiegały znacznie na przykład od siedziby prokuratorskiej w Piszu. Różnicą było z pewnością umiejscowienie tego obiektu w linii umocnień miejskich.

Wyniki badań archeologicznych w Iławie okazały się niejednoznaczne. Na wyspie Wielka Żuława przebadano gródek stożkowaty (Wysocki, Klęczar 2013). Przypuszczano, że w tym miejscu znajdowała się pierwsza siedziba zakonna w okolicy, później przeniesiona zapewne na teren miasta. Niedawno zaprezentowano także nowożytną mapę (ryc. 2), na której widoczna jest wspomniana wyspa, a na niej zamek z dwoma domami (Lasek, Przypkowski 2013). Przekonujące wydają się wyjaśnienia Piotra Laska i Seweryna Szczepańskiego, że mamy do czynienia z prywatną siedzibą powstałą prawdopodobnie w 1. połowie XVI wieku (Lasek, Szczepański 2016). Przy obecnym stanie badań możemy więc przyjąć, że siedziba tamtejszego prokuratora stanowiła dwór miejski.

Niestety, nie dotarłem do wyników badań archeologicznych w Miłomłynie, ale $\mathrm{z}$ ustnych informacji autorów badań wiadomo, że siedziba krzyżacka była nieco większa niż do tej pory przypuszczano. Z drugiej strony niewielki zakres badań nie pozwala wciąż na zrekonstruowanie tego założenia. Dotychczasowe rekonstrukcje opierają się na szkicu Johanna M. Guise z lat 20. XIX wieku (ryc. 3), jest on jednak na tyle schematyczny i niedokładny, że może tylko w niewielkim stopniu służyć jako punkt odniesienia do odtworzenia wyglądu wspomnianego założenia.

Interesująco prezentuje się kwestia siedziby prokuratorskiej w Mątowach Małych. Już od XIV wieku funkcjonował tam folwark, na początku XV wieku nastąpiła jego rozbudowa lub budowa nowego obiektu. Prokurator rezydował zapewne w bardzo długim budynku (około $13 \times 140$ m), w którym znajdowały się także inne pomieszczenia, na przykład kuchnia, kaplica, ale również pomieszczenia do przetrzymywania zwierząt hodowlanych. 


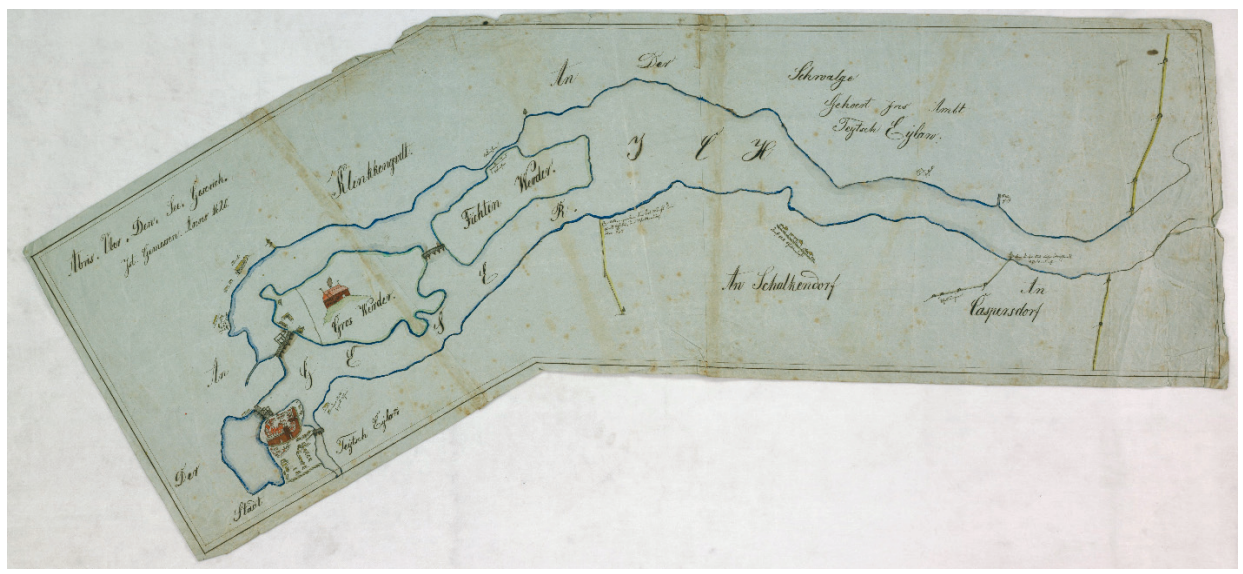

Ryc. 2. Iława wraz z okolicznymi miejscowościami i zamkiem na wyspie Wielka Żuława; XVIII wiek(?). Najprawdopodobniej przerys planu z 1620 roku (wg Lasek, Przypkowski 2013)

Fig. 2. Iława and neighbouring localities as well as the castle on Wielka Żuława Island; the $18^{\text {th }}$ century(?). Most likely a copy of the plan from 1620 (after Lasek, Przypkowski 2013)

Pozostaje kwestia badań archeologicznych w Tczewie. W 2009 roku przy ulicy Zamkowej natrafiono na fundamenty dużej murowanej budowli średniowiecznej o wymiarach 10-12×27 m, które uznano za pozostałość jednego ze skrzydeł zamku (Jonakowski b.d.w.). W jego wnętrzu znajdowały się przynajmniej dwa pomieszczenia. Natrafiono także na relikty murowane, które wstępnie zinterpretowano jako pozostałości wieży. Nie należy jednak, moim zdaniem przesądzać, że są to pozostałości siedziby wójtowskiej, ponieważ wójtowie tczewscy rezydowali także w Sobowidzu i Zajączkowie. Mogą one stanowić pozostałość niezwiązanych z korporacją zakonną zabudowań. W przyszłości konieczne wydaje się rozpoznanie zasięgu tego założenia oraz określenie skali i rozplanowania pozostałej zabudowy, a także uściślenie datowania.

Przedmiot badań archeologicznych stanowiło więcej obiektów rezydencjonalno-obronnych związanych z Zakonem, a niebędących siedzibami konwentów. W pozostałych przypadkach trudno jednak stwierdzić, jaka była ich rola w systemie administracyjnym państwa (np. Słoszewy, Gródek koło Drzycimia). Nie wspomniałem także o przedwojennych badaniach i przypadkowych odkryciach, na przykład w Szczytnie, Działdowie, Mortągu i Gródku, nieudokumentowanych w sposób naukowy.

Jak wynika z przedstawionego powyżej przeglądu obiektów stanowiących siedziby średnich i niższych rangą urzędników krzyżackich, występujące w literaturze określenia: ,zamek o planie wójtowskim”, „,zamek o planie prokuratorskim”, „zamek o planie komornickim” (Wółkowski 2013, s. 114, ryc. 1) wprowadzają 


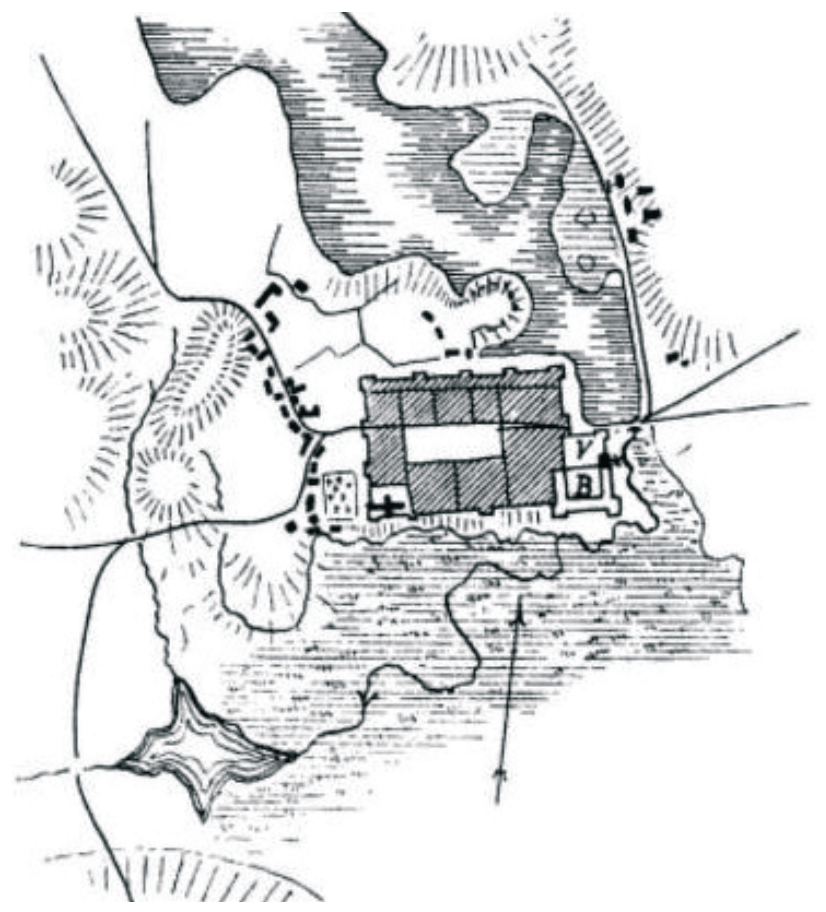

Ryc. 3. Miłomłyn. Zamek według szkicu autorstwa J. M. Guise, lata 20. XIX wieku (wg Boetticher 1898)

Fig. 3. Miłomłyn. The castle after a sketch by J. M. Guise, 1820s (after Boetticher 1898)

w błąd. Należy odrzucić stosowanie terminów nawiązujących do rangi danego urzędu, jako opisujących kształt i wielkość założeń architektonicznych.

Siedziby urzędników krzyżackich poniżej rangi komtura były bardzo zróżnicowane pod względem skali i rozplanowania. Możemy wskazać na monumentalne zamki wójtów i prokuratorów oraz mniejsze założenia stanowiące siedziby zarówno rybickich, leśnych i komorników, jak i wspomnianych wyżej urzędników. Z całą pewnością dominowały wśród nich obiekty regularne. Przy obecnym stanie badań trudno określić proporcję między siedzibami murowanymi a drewniano-ziemnymi. Wyniki badań archeologicznych świadczą jednak o tym, że na obszarze tzw. Prus Właściwych w ostatniej ćwierci XIV wieku zastępowano mniej trwałe obiekty założeniami murowanymi. Możemy także zaobserwować tendencję do wznoszenia w obrębie obwodów warownych, w 2. połowie XIV wieku, mniejszych domów murowanych. W świetle dotychczasowych prac terenowych oraz uwzględniając obiekty, które zachowały się do dzisiaj, wydaje się, że zdecydowanie przeważały one nad dużymi domami zamkowymi. Z 2. połowy XIV wieku pochodzi jeden zamek z domem, którego długość przekraczała $50 \mathrm{~m}$ (Węgorzewo), natomiast z 1. połowy stulecia znamy przynajmniej trzy takie 
założenia - w Pasłęku, Przezmarku i Sztumie. Z drugiej strony znamy dużo więcej siedzib z domami murowanymi, których długość nie przekraczała $30 \mathrm{~m}$, datowanych na 2. połowę XIV wieku (np. w Olsztynku, Szestnie, Giżycku, Ełku, Bezławkach, Pucku) niż z okresu wcześniejszego. Można wskazać na zamek w Sątocznie i Nowym Jasińcu, pamiętając, że początek budowy drugiego z nich może sięgać czasów przedkrzyżackich.

Zdaniem T. Torbusa w ciągu ostatnich 30 lat jedynie badania konwentualnego zamku w Dzierzgoniu i wójtowskiego w Morągu wpłynęły znacząco na wiedzę i wyobrażenie o kształcie tych siedzib (Torbus 2013, s. 68). Sądzę jednak, że dotyczy to także innych obiektów, na przykład zamku w Olsztynku, dla którego uzyskano nowe dane dotyczące jego formy w średniowieczu. W Sątocznie wyniki badań pozwoliły na rekonstrukcję założenia, wcześniej pozostającego przecież nierozpoznanym, w Ełku natomiast w znacznym stopniu uszczegółowiły wiedzę o tamtejszym zamku. W kilka lat po napisaniu tych słów przez T. Torbusa można wymienić kolejne prace archeologiczne, które dostarczyły licznych nowych informacji nie tylko w odniesieniu do siedzib niższych urzędników. Przykładem mogą być badania Marcina Wiewióry i jego zespołu na terenie ziemi chełmińskiej, realizowane w ramach projektu naukowego pt. „Castra Terrae Culmensis - na róbieży chrześcijańskiego świata".

Na zakończenie należy powtórzyć stwierdzenie, że błędne stosowanie określeń „model zamku wójtowskiego”, „model zamku prokuratorskiego”, „model zamku komornickiego". Siedziby krzyżackie poniżej rangi komtura nie miały form przyporządkowanych do danej rangi urzędników. Zamki i dwory stanowiące siedziby prokuratorów mogły mieć podobną skalę co wójtowskie, a siedziby komorników nie musiały odbiegać znacznie od siedzib wójtów. Warto wspomnieć, że zamki początkowo stanowiące siedziby prokuratorów, w niektórych wypadkach z czasem stawały się siedzibami wójtów (np. Przezmark, Pasłęk, Działdowo). Nie ma jednak przesłanek, które sugerowałyby ich rozbudowę wraz ze zmianą tytulatury tamtejszych urzędników. W 1. połowie XIV wieku powstawało więcej długich domów zamkowych, podczas, gdy w 2. połowie tego stulecia liczniej wznoszono domy, które można określić jako krótkie. Nie należy jednak wykluczyć, że stwierdzenie to jest jedynie wynikiem stanu badań.

Chciałbym również poddać w wątpliwość tezę odnośnie do wpływu zamków konwentualnych na architekturę siedzib średnich i niższych rangą urzędników krzyżackich. Wydaje się, że założenia te należy rozpatrywać w dużo szerszym kontekście architektury południowego pobrzeża Morza Bałtyckiego. Nie miały one cech, wyróżniających je na tle pozostałej architektury obronnej tej części Europy i nie tworzyły jednolitej grupy, w przeciwieństwie do znacznej części zamków konwentualnych. 


\section{Literatura}

Andrzejewski A., Kajzer L.

2001 Sprawozdanie z badań archeologiczno-architektonicznych przeprowadzonych na terenie zamku w Sątocznie, gm. Korsze, woj. warmińsko-mazurskie w 2001 roku, Łódzkie Sprawozdania Archeologiczne, t. 7, s. 289-307.

2002-2003 Zamek krzyżacki w Satocznie, w gminie Korsze, w świetle badań terenowych 2002 roku, Łódzkie Sprawozdania Archeologiczne, t. 8, s. 237-251.

2005 Zamek w Satocznie w „,Terra Barthensi” albo triumf historii, [w:] XIV Sesja Pomorzoznawcza, t. 2: Od wczesnego średniowiecza do czasów nowożytnych, red. H. Paner, M. Fudziński, Gdańsk, s. 197-206.

Bötticher A.

1898 Die Bau und Kunstdenkmäler der Provinz Ostpreußen, t. 3, Königsberg.

Bezławki

2013 Bezławki. Ocalić od zniszczenia, red. A. Koperkiewicz, Gdańsk.

Blusiewicz K.

2008 Sprawozdanie $\mathrm{z}$ badań archeologicznych przeprowadzonych na zamku w Działdowie w 2008 roku, maszynopis w archiwum Wojewódzkiego Urzędu Ochrony Zabytków w Olsztynie, Warszawa.

Buczek-Płachtowa B.

1969 Sprawozdanie z pierwszego sezonu badań archeologicznych na zamku w Szczytnie, prowadzonych w okresie od 12 V 1969 do 10 VII 1969, maszynopis w archiwum Wojewódzkiego Urzędu Ochrony Zabytków w Olsztynie, Warszawa.

1970 Szczytno zamek krzyżacki, wstępne wyniki badań 14 VII-24 IX 1970, maszynopis w archiwum Wojewódzkiego Urzędu Ochrony Zabytków w Olsztynie, Warszawa.

Chęć A.

2003a Badania archeologiczne na terenie dawnego folwarku w Matowach Małych, gm. Miłoradz na Żuławach Wiślanych - sezon badawczy 2001, [w:] XIII Sesja Pomorzoznawcza, t. 2: Od wczesnego średniowiecza do czasów nowożytnych, red. H. Paner, M. Fudziński, Gdańsk, s. 393-401.

2003b Der Ordenshof in Matowy Małe (Klein-Montau): die Ergebnisse der archäologischen Ausgrabungen im Jahr 2001, [w:] Die Ritterorden in der europäischen Wirtschaft des Mittelalters, red. R. Czaja, J. Sarnowsky, Torun, s. 183-195.

2004 O siedzibie leśniczego krzyżackiego w Benowie, Kwartalnik Kwidzyńskiego Towarzystwa Kulturalnego", nr 4, s. 4-5.

Chęć A., Janowski P.

2005 Badania archeologiczne na terenie dawnego folwarku i siedziby leśniczego krzyżackiego w Benowie, gm. Ryjewo na Dolnym Powiślu - sezony badawcze 2002 i 2003, [w:] XIV Sesja Pommorzoznawcza, vol. II od wczesnego średniowiecza do czasów nowożytnych, red. H. Paner, M. Fudziński, Gdańsk, s. 355-360. 
Czubiel L.

1986 Zamki Warmii i Mazur, Olsztyn.

Dąbrowski J.

1961/1962 Badania w Dąbrównie, Rocznik Olsztyński 4, s. 341-356.

Durdík T.

1994 Kastellburgen des 13. Jahrhunderts in Mitteleuropa, Wien-Köln-Weimar.

1998 Česká hradni architektura doby Jana Lucemburského, Castellologia bohemica, t. 6/1, s. 7-69.

Frycz J.

1978 Architektura zamków krzyżackich, [w:] Sztuka pobrzeża Bałtyku. Materiały Sesji Stowarzyszenia Historyków Sztuki, Gdańsk, listopad 1976, Warszawa, s. $19-48$.

Gardawski A.

1958 Wyniki archeologicznych badań terenowych, przeprowadzonych na zamku w Działdowie w lipcu 1958 roku, Warszawa, maszynopis w archiwum Wojewódzkiego Urzędu Ochrony Zabytków w Olsztynie, Warszawa.

Głosek M.

1986 Wstępne wyniki badań archeologiczno-architektonicznych zamku w Szestnie, gm. Mrągowo w 1986 r., maszynopis w archiwum Wojewódzkiego Urzędu Ochrony Zabytków w Olsztynie, Łódź.

Grążawski K.

2010 Od Kurzętnika do Bratiana. Inicjalna faza bitwy grunwaldzkiej, Komunikaty Mazursko-Warmińskie, nr 3, s. 301-316.

2015 Koncepcja i wstępne wyniki badań w Kurzętniku i Bratianie, [w:] Materiały do archeologii Warmii i Mazur, t. 1, red. S. Wadyl, M. Karczewski, M. Hoffmann, Warszawa-Białystok, s. 367-372.

Grążawski K., Grążawska N.,

2013 Inicjalna faza bitwy grunwaldzkiej. Wyniki archeologicznych badań podwodnych i weryfikacjno-sondażowych w Kurzętniku i Bratianie, [w:] XVII Sesja Pomorzoznawcza, t. 2: Od późnego średniowiecza do czasów nowożytnych, Grzegorz M. red. H. Paner, M. Fudziński, Gdańsk, s. 571-578.

1997 Pomorze Gdańskie pod rzadami Zakonu krzyżackiego w latach 1308-1466, Bydgoszcz.

Grzywacz Ł.

2003 Siedziby drobnych urzędników krzyżackich na ziemi chełmińskiej, Pomorzu Gdańskim, Warmii i Mazurach, maszynopis pracy magisterskiej w archiwum Instytutu Archeologii Uniwersytetu Łódzkiego, Łódź.

Gula J.

2003a Badania archeologiczne prowadzone w 2003 roku na terenie zamku w Piszu, Znad Pisy, nr 12, s. 14-43.

2003b Morąg - zamek. Badania i nadzory archeologiczne 2002 r., maszynopis w archiwum Wojewódzkiego Urzędu Ochrony Zabytków w Olsztynie, Delegatura w Elblągu, Raciszewo. 
Gula J., Ślaske M.

1969 Giżycko, pow. loco, woj. Olsztyńskie. Badania archeologiczne w 1969 r., maszynopis w archiwum Wojewódzkiego Urzędu Ochrony Zabytków w Olsztynie, Delegatura w Ełku, Warszawa.

Herman R.

2012 Zamek w Ełku. Wstępne sprawozdanie z badań archeologicznych. Sezon 2012. Zabudowa części północnej, maszynopis w archiwum Wojewódzkiego Urzędu Ochrony Zabytków w Olsztynie, Delegatura w Ełku, Łódź.

2015 Zamek w Ełku. Tajemnice wydobyte z przeszłości, Ełk-Łódź.

Hołowińska Z.

1975 Zamek Kiszewski, pow. Kościerzyna. Stanowisko 1, Informator Archeologiczny. Badania rok 1974, Warszawa, s. 214.

Jackiewicz-Garniec M., Garniec M.

2009 Zamki państwa krzyżackiego w dawnych Prusach, Olsztyn.

Jähnig B.

2000 Wykaz urzędów. Dostojnicy zakonu krzyżackiego w Prusach, [w:] Państwo zakonu krzyżackiego w Prusach. Podziały administracyjne i kościelne w XIIIXVI wieku, red. Z. H. Nowak, Toruń, s. 95-127.

Jonakowski M.

b.r.w. Sprawozdanie wstępne z przeprowadzonych badań wykopaliskowych na obszarze działki nr 418/14 przy ul. Zamkowej w Tczewie, maszynopis w archiwum Wojewódzkiego Urzędu Ochrony Zabytków w Gdańsku, Elbląg.

Jóźwiak S.

$2000 \quad$ Powstanie i rozwój struktury administracyjno-terytorialnej Zakonu Krzyżackiego na poludniowych obszarach Prus Górnych do 1410 r., Komunikaty Mazursko-Warmińskie, nr 1, s. 3-27.

2012 Centralne i terytorialne organy władzy zakonu krzyżackiego w Prusach w latach 1228-1410. Rozwój - przekształcenia - kompetencje, Toruń.

Kajzer L.

2007 Z problematyki wplywów budownictwa warownego Krzyżaków na zamki Niżu Polskiego, Archaeologia Historica Polona, t. 17, s. 259-272.

Knyżewski M.

2015 Zamek w Działdowie na tle architektury obronnej Zakonu, Komunikaty Mazursko-Warmińskie, nr 2, s. 255-267.

Kochanowski M.

1998/1999 Krzyżacki dwór obronny w Grabinach-Zameczku w świetle nowych badań archeologicznych, [w:] Z otchłani wieków Pomorza Gdańskiego, Koperkiewicz A. red. J. Bojahr, Gdańsk, s. 85-92.

2007 Sprawozdanie z badań archeologicznych w Olsztynku, stanowisko II (zamek) AZP 28-59/21 2007, maszynopis. w archiwum Wojewódzkiego Urzędu Ochrony Zabytków w Olsztynie, Gdańsk. 
Koperkiewicz A., Świętosławski W.

2006 Sprawozdanie z badań archeologicznych w Olsztynku. Stanowisko II (zamek) AZP 28-59/21, Olsztyn, maszynopis w archiwum Wojewódzkiego Urzędu Ochrony Zabytków w Olsztynie, Gdańsk.

Kruppé J., Milewska M.

2014 Dzieje zamku w Pucku, Warszawa.

Lasek P., Przypkowski J.

2013 Najstarszy widok Iławy i zamku na Wielkiej Żuławie z 1620 roku w zbiorach Instytutu Sztuki PAN, [w:] Grodziska Warmii i Mazur 1. Stan wiedzy i perspektywy badawcze. Archaeologica Hereditas 2, red. Z. Kobyliński, Warszawa-Zielona Góra, s. 381-384.

Lasek P., Szczepański S.

2016 Z dziejów pewnego zastawu. Czyli „zamek” Deutsch-Eylau alias „dwór” Gross Werder, Biuletyn Historii Sztuki, R. 78, nr 3, s. 431-458.

Łapo J. M.

1996 Sprawozdanie z sondażowych badań wykopaliskowych przeprowadzonych na dziedzińcu zamku w Wegorzewie w 1995 roku, Studia Angerburgica, t. 1, s. $78-83$.

1999 Onajnowszych i najciekawszych odkryciach archeologicznych dokonanych na terenie Starego Miasta w Wegorzewie, Studia Angerburgica, t. 4, s. 113-119.

Milewska M.

1990 Sprawozdanie $\mathrm{z}$ badań archeologicznych prowadzonych na zamku w Działdowie w latach 1981-1989, maszynopis w archiwum Wojewódzkiego Urzędu Ochrony Zabytków w Olsztynie, Warszawa.

1993 Zamek w Skarszewach. Próba rekonstrukcji dziejów założenia, Pomorania Antiqua, t. 15, s. 141-153.

Muntowski P.

2013 Architektura zamku krzyżackiego i rezydencji starostów w Osieku w świetle badań archeologicznych, [w:] XVII Sesja Pomorzoznawcza, t. 2: Od późnego średniowiecza do czasów nowożytnych, red. H. Paner, M. Fudziński, Gdańsk, s. 243-261.

Nawrocki Z.

1967 Zamek w Jasińcu Nowym, Bydgoskie Towarzystwo Naukowe. Prace Wydziału Nauk Humanistycznych, seria D, nr 4, Prace Komisji Sztuki 2, Bydgoszcz. Partyka-Żurowska D.

1977 Nowe n/Wisłą. Stanowisko 1 - Zamek. Badania wykopaliskowe 1977, maszynopis w archiwum Wojewódzkiego Urzędu Ochrony Zabytków w Toruniu, Delegatura w Bydgoszczy, Grudziądz.

Pawłowski A. J.

1993 Zamek w Bytowie. Dokumentacja archeologiczno-architektoniczna. Część I, maszynopis w archiwum Wojewódzkiego Urzędu Ochrony Zabytków w Gdańsku, Delegatura w Słupsku, Malbork.

1994 Zamek w Bytowie. Przewodnik, Słupsk. 
Pietrzak J.

2005 „Dwudomowe”, nizinne zamki średniowieczne i ich dziedzińce w prowincji Wielkopolskiej, Archaeologia Historica Polona, t. 15/1, s. 207-233.

Piotrowski A.

2010 Sprawozdanie z wyprzedzających badań archeologicznych prowadzonych przy zamku w Giżycku. Obszar pomiędzy północną ścianą zamku a ulicą Moniuszki, maszynopis w zbiorach autora, Ostróda.

2011 Zamek giżycki. Sprawozdanie z prac prowadzonych przy eksploracji zasypów odsłoniętych reliktów gotyckiego gdaniska, maszynopis w zbiorach autora, Ostróda.

Poklewski T.

1992 Dąbrówno, woj. olsztyńskie, Informator Archeologiczny. Badania. Rok 1988, Warszawa, s. 123.

Poliński D.

2013 Pień. Siedziba krzyżackich prokuratorów w ziemi chetmińskiej, Toruń. Szczepanik P.

2013a Opracowanie wyników badań archeologicznych na stanowisku AZP 15-33/74m.1 w Bytowie, pow. bytowski, woj. pomorskie w okresie 30.09.05.10.2013 r., maszynopis w archiwum Wojewódzkiego Urzędu Ochrony Zabytków w Gdańsku, Delegatura w Słupsku, Bytów.

2013b Studnia bytowskiego zamku. Opracowanie archeologiczne, maszynopis w archiwum Wojewódzkiego Urzędu Ochrony Zabytków w Gdańsku, Delegatura w Słupsku, Bytów.

Torbus T.

1997 Die Deutschordensburg von Sthum (Sztum) im ehemaligen Ordensland Preußen, [w:] Der frühe Schloßbau und seine mittelalterlichen Vorstufen, red. H. Hofrichter, G. U. Grossmann, Forschungen zu Burgen und Schlössern 3, München, s. 171-184.

2010 Zamki krzyżackie, Warszawa.

2013 Zamki krzyżackie na terenie pruskiego państwa Zakonu. Uwagi na temat stanu badań, perspektywy badawcze oraz zachowanie obiektów, [w:] Conflictus Magnus Apud Grunwald 1410. Między historia a tradycją, red. K. Ożóg, J. Trupinda, Malbork, s. 65-70.

2014 Zamki konwentualne państwa krzyżackiego w Prusach, Gdańsk.

Voigt J.

1843 Namen Codex der Deutschen Ordens-Beamten, Hochmeister, Landmeister, Großgebietiger, Komthure, Vögte, Pfleger, Hochmeister-Kompane, Kreuzfahrer und Söldner-Hauptleute in Preussen, Königsberg.

Wasik B.

2016 Budownictwo zamkowe na ziemi chetmińskiej od XIII do XV wieku, Toruń. Wołosz A. K. F.

1998 W sprawie rozplanowania murowanego zamku w Wegorzewie, Studia Angerburgica, t. 3, s. 8-29. 
Wółkowski W.

2013 Architektura zamku w Bezławkach, [w:] Bezławki, s. 109-118. Wysocki J., Klęczar B.

2013 Grodziska typu stożkowatego na wyspie Wielka Żuława w Iławie, w Lasecznie Małym i Mózgowie w powiecie iławskim: wstępne wyniki badań z 2012 r., [w:] Grodziska Warmii i Mazur 1. Stan wiedzy i perspektywy badawcze. Archaeologica Hereditas 2, red. Z. Kobyliński, Warszawa-Zielona Góra, s. $327-350$.

\section{FORMS OF MEDIUM AND LOWER RANK TEUTONIC ORDER OFFICIALS' SEATS WITHIN THE BORDERS OF PRESENT POLAND}

Keywords: Teutonic Order's castles, state of research, Teutonic Order's manors, Teutonic Order's Prussia, defensive architecture, Middle Ages, archaeology.

Summary

On the teritory of todays Poland we can point to about seventee castles and mansions, which were the headquarters of officials, with the exception of commanders, serving, in general, the administrative function. Nearly half of them were the subject of excavations. In the article, I present the state of excavation research on the title objects.

In literature one can still find erroneous opinions concerning the architecture of smaller resitentional objects of the Teutonic Order. The literature is dominated by the conviction that the largest seats of officials were the voigts' castles, next the procurators' castles, and that the smallest ones were the bailiffs' castles. But there were individual procurators' castles that were even larger than most of voigts' seats, such as, for example, the building in Węgorzewo. It should be also noted that the procurator's castle in Szestno was almost twice smaller from castle in Bezławki. 